\title{
Rejuvenating The Face of Medan
}

\author{
S. Azura* and W. Utami \\ Architecture Department, Faculty of Engineering, Universitas Sumatera Utara, Medan, Indonesia \\ *email: syahirah101@gmail.com \\ Submitted: 12 January 2020 Revision: 20 January 2020 Online: 29 January 2020
}

\begin{abstract}
Medan is the third-largest city in Indonesia, and so do their heritage. The historic building in Medan City is a valuable asset. These buildings have infinite value and essential to people that ever lived there. Throughout more than five generations, these shophouses are stood still until today and waiting to be eaten by age. Therefore, this area should be conserved. Buildings that lived in Pasar Hindu slowly become extinct because of ignorance from people. Thus, an act of revitalization to this place should be done to conserve the story that ever recorded in this place, so that our next generations can learn and appreciate our history. This project is about how architecture can act as preservation in the historical area throughout the environmental design by the methodological approach. Heritage is a beautiful theme that keeps the scent and the scars of old stories that ever crouched at the shophouse. Compared to other countries that have successfully rejuvenate their historic buildings, their achievements developed much more than building façade but also increased the economic income of the community. These historical buildings had finally become a valuable asset for the owner, precious gems to the city, and pride to the nations.
\end{abstract}

Keywords: Architecture, History, Heritage, Shophouse.

\section{INTRODUCTION}

Perdana Street is a popular place for the trading area of the Tionghwa's community, as well as the residential community of river-lined Malays who lived ever since the era of Kesultanan Melayu Deli. These people lived and worked for generations passing through their children. This area has a traditional market called Pasar Hindu. It is the shortest market ever found in Medan. The market location is near the river, whereas lived by the Malays, while the shophouses lived by the Chinese people. Therefore, it has been acting as an activity generator for years.

Perdana Street is the only way to reach this place. This road has blocks of old shophouses facing the roads attached. As we drive through Perdana Street, we can see that most of the shophouses are closed or inactive. Unfortunately, a historic building in Medan City gets treated this way.

The design process of this project is to revitalize the existing Heritage building around this area to develop its potential river basin as so to be able to bring benefits to the surrounding.

Location and Site

Project location of Rejuvenating the face of Medan is at Perdana Street dan Pasar Hindu, Kelurahan Kesawan, Kecamatan Barat, Medan. This area limits are reaching the Deli River. The site function as commercials, residential, and public areas. The areas that included in this project are $2.8 \mathrm{Ha}$ (Figure 1).

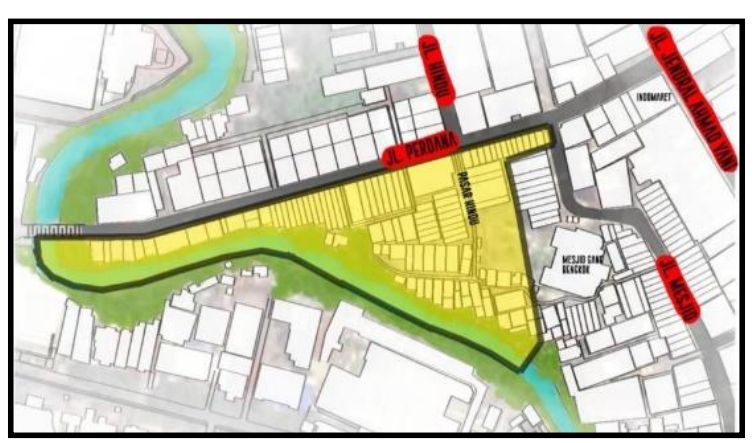

Figure 1. Project Location

\section{Theme}


The theme of this project is heritage. UNESCO defines heritage as a legacy or a past culture, what humans currently live, and what is passed on to future generations. Therefore, the heritage theme is purposed to customize the cultural heritage to the design of the building. That is, the buildings included in this planning area will be built according to the culture of the people there.

For example, if the shop owner on $\mathrm{Jl}$. Perdana is Chinese society, then the design of the shop is following the culture and function of the shophouse. So the shape of the building facade will be redesigned according to ancient typology with Chinese culture (Figure 2). The windows with the same designs with new colors, plus ornaments, or others that characterize the identity of the community in antiquity will replace the old broken windows.

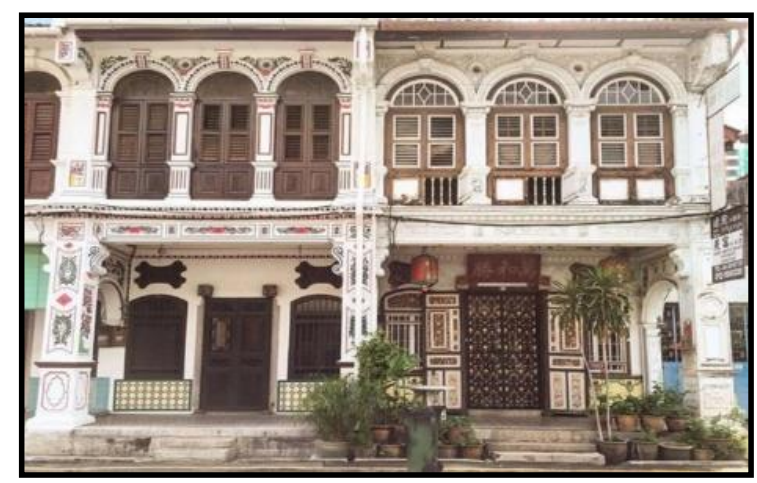

Figure 2. Chinese Shophouse Facade

\section{Comparative Study}

The city of Medan, especially on Perdana Street, needs to learn from neighboring countries, Singapore. In the 1970s, the modern styles have replaced the colonial-style buildings that once became the face of Singapore. However, in times of economic crisis due to sharp declining petroleum prices, the Singapore government rushed to restore the buildings to the original form, and then make the area of the Heritage area. The goal is to highlight the distinctiveness of Singapore as well as to maintain the old building's uniqueness. The development of this area makes it becomes an attractive tourist area. As a result, many tourists from all over the country came to this place. Singapore is getting a sharp spike in tourist visits to the country each year. Until now, Singapore managed to be a pioneer in Southeast Asia in developing heritage-themed tourism [1].
The lesson learned from the case facing Singapore is how they succeeded in maintaining existing historical and cultural values and used it as a spike stone to carry the country's famous name throughout the country. As with the case on Perdana Street, supposedly with buildings that have a Heritage value, we should not let him die and be neglected (Figure $3)$.

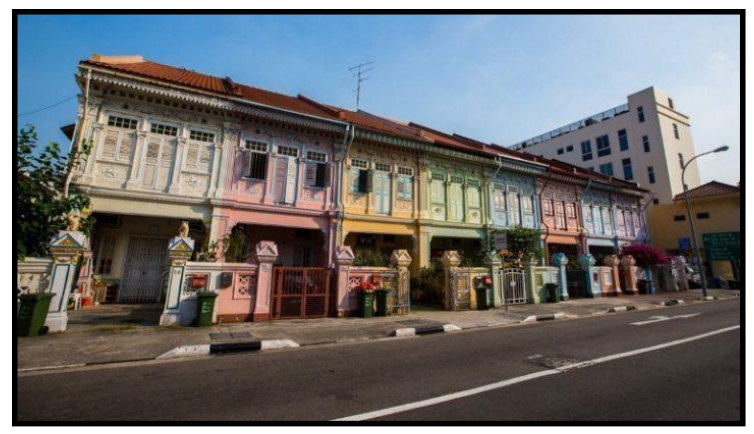

Figure 3. Heritage Building by the government in Singapore

\section{METHODS}

In this study, using this type of method of the glass box design. This model believes that the design process can be conducted in a rational and systematic. As with a computer, the brain receives feedback, which examines programmatically, analytical, evaluative, and sites so that we will get a solution of optimization that may be performed. Using two types of data, which is the Primer and the Secondary data through two processes, which are observation, where the method used to collect data by observing through the entire project collected, and also by studying literature, a method used by collecting data from studying data. Primary data is the data that is obtained by going to the location and observing directly to the site. One of the data obtained is the location site maps, physical existing appearance data, and a photograph of observation in location. Secondary data is data that is obtained directly without going to go to the location site. Data obtained are the data of RDTR, study literature, and comparative study.

\section{RESULTS AND DISCUSSION}

Before this revitalization take place, analyzing was done to find out how many 'idle' shophouses detected at the location of the 
project (Figure 4). The goal is to extract the types of typical shophouses available according to their typology by counting their percentage (Table 1).

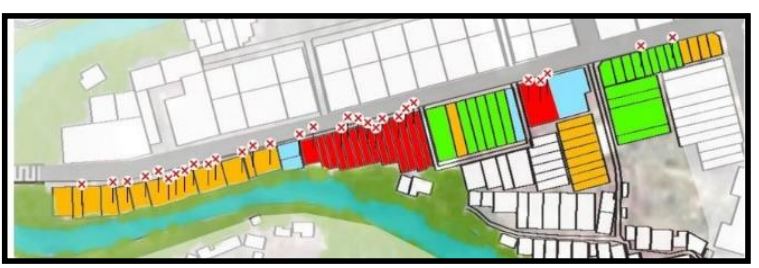

Figure 4. To determine whether which shophouse is inactive

Table 1. Shophouse analysis

\begin{tabular}{lccc}
\hline Shophouse & Active & Inactive & $\begin{array}{c}\text { Percent } \\
\text { age }\end{array}$ \\
\hline $\begin{array}{l}\text { Perdana } \\
\text { Street }\end{array}$ & 31 & 34 & $47 \%$ \\
$\begin{array}{l}\text { Hindu } \\
\text { Market }\end{array}$ & 14 & 1 & $93 \%$ \\
\hline $\begin{array}{l}\text { Sums } \\
\text { percentage } \\
\text { Active }\end{array}$ & & & $\mathbf{5 6 \%}$ \\
\hline
\end{tabular}

The table above shows that only $47 \%$ of shophouses are active on Jl. Perdana, where this figure is less than half of the total. Compared with the shop in the Pasar Hindu as much as 93\% that is almost all were active. Shophouse on Perdana Street is active due to the existence of Pasar Hindu, which acts as Activity Generator, as regards to the proximity of shophouses from the Pasar Hindu. Shophouse in the market, almost all of life compared with the shop on Perdana Street. The peace generated from the market has brought the shophouse atmosphere to keep moving and visited by people. This point indicates that the existence of an Activity Generator significantly affects the continuity of activity in a region.

After knowing the percentage and which shophouse should be renovated, the next step is to compare with the results of field surveys. The data collected is comparing the existing shop facades in the project area (Figure 5) with the theory used to know the type of shop group used in Perdana Street. Here are the results of field surveys (Table 2).

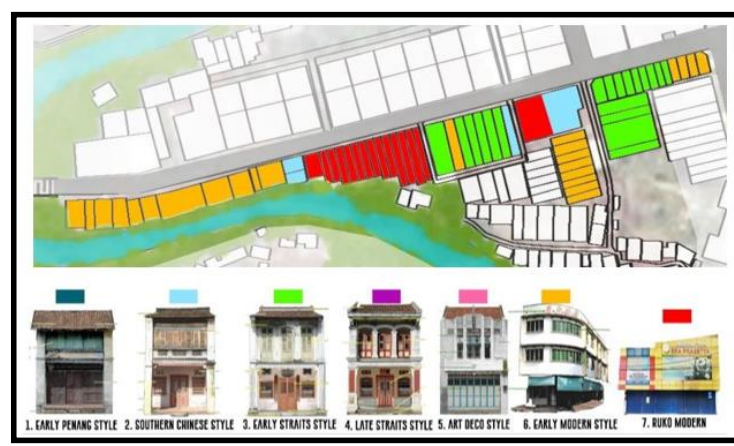

Figure 5. To determine what types of shophouse available at the site

Table 2. Shophouse Typology Analysis

\begin{tabular}{llr}
\hline No. & Shophouse Typology & Inactive \\
\hline 1 & Early Penang Style & 0 \\
2 & Southern Chinese & 6 \\
& Style & \\
3 & Early Straits Style & 22 \\
4 & Late Straits Style & 0 \\
5 & Art Deco Style & 0 \\
6 & Early Modern Style & 32 \\
7 & Modern Shophouse & 20 \\
\hline Total & & $\mathbf{8 0}$ \\
\hline
\end{tabular}

According to the table above, there is four typology shop which dominated in the project area. They are Southern Chinese Style, Early Straits Style, Early Modern Style, and Modern Shophouse.

After making an analyzing upon the types of shophouses that will be bought to conservation, the next step is constructing a design for the project, which is designing the architecture of the buildings. For the conservation project, shophouses will be renovated according to their origin typology. For the development project, a new design of space, which includes information theories of the environment, will be applied to this location. This theory is based on the elements that been bought to settle down an urban landscape. The elements that been applied to this project are Permeability, Variety, Richness, and Personalisation. These elements are set up into this area so that this area can be thought of as one themed place [2]. This development area aims to use the river potential (Deli River) located in this project area (Figure 6). 


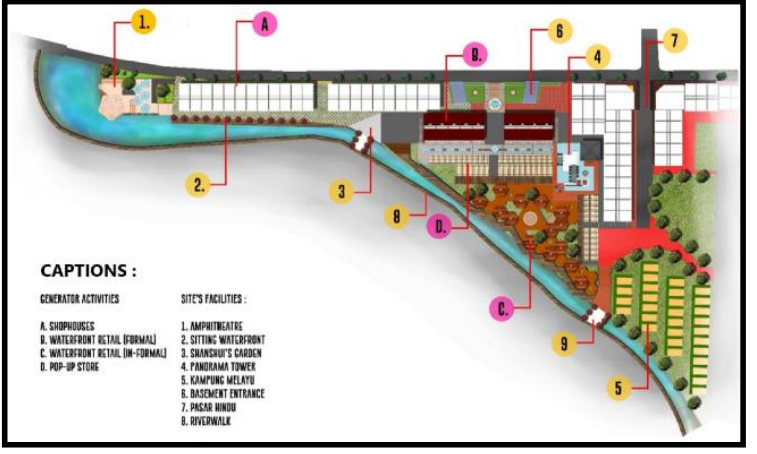

Figure 6. Siteplan of Project Location

This area involved more than one type of building and has various functions. These buildings are arranged based on their proximity, or known as their path of motions. A relationship between buildings is significant, and how humans will interact in this place should be considered when arranging the functions [3].

\section{CONCLUSION}

After making an investigation and observation, the conclusion that the location project is suitable for revitalization according to the building typologies. This act is made to ensure that this historic building can last long for the future. Besides conservation, the location project is also suitable for making development because of its potential due to the river. Development can be made such as designing a space for the villagers to interact and grow on their own, such as the waterfront retail that will help to increase their economic income, The Kampung Melayu area that will attract tourist to discover their culture, and also the Riverwalk that can attract locals especially Medan-ers that have lack of open space today.

Medan City is a city that has various of history that came along with heritage building afterward. This building tells a story of how our culture becomes various and also how our ancestors adapt themselves self, especially the immigrants. Conservation should be done to become united in the future so that the next generation can feel and know how history can change people and the world.

\section{ACKNOWLEDGMENT}

This article is written by researchers who are partly funded by the University of Sumatera Utara and was given out as a donation to the government to preserve and improve the value of design, local wisdom, arts, and ethnic.

\section{REFERENCES}

[1] Tan Y. W. Penang Shophouses A handbook of Features and Materials. Singapore. 2015.

[2] Bently A. Responsive Environments. London. 1985.

[3] Francis D.K.C. Architecture Form, Space, \& Order (Third Edition). Jakarta: Erlangga. 2008. 